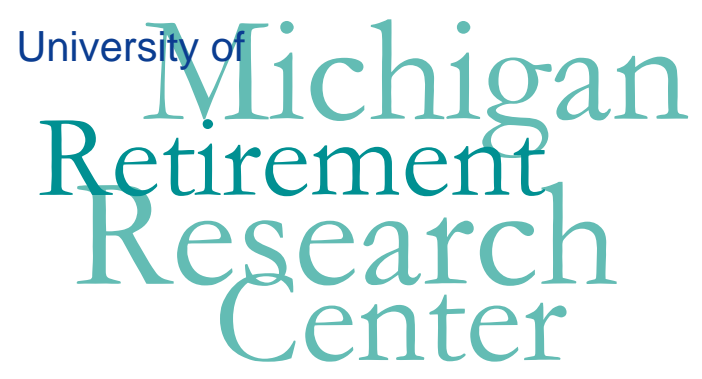

Working Paper WP 2009-203

\title{
The Efficiency of Pension Menus and Individual Portfolio Choice in 401(k) Pensions
}

Ning Tang, Olivia S. Mitchell, Gary Mottola, and Steve Utkus

\begin{tabular}{|l|l|}
\hline $\mathrm{M}$ & $\mathrm{R}$ \\
\hline $\mathrm{R}$ & $\mathrm{C}$ \\
\hline
\end{tabular}$\quad$ Project \#: UM09-07 


\title{
The Efficiency of Pension Menus and Individual Portfolio Choice in 401(k) Pensions
}

\author{
Ning Tang \\ Olivia S. Mitchell \\ The Wharton School, University of Pennsylvania \\ Gary R. Mottola \\ Stephen P. Utkus \\ Vanguard Center for Retirement Research
}

\author{
August 2009 \\ Michigan Retirement Research Center \\ University of Michigan \\ P.O. Box 1248 \\ Ann Arbor, MI 48104 \\ http://www.mrrc.isr.umich.edu/ \\ (734) 615-0422
}

\section{Acknowledgements}

This work was supported by a grant from the Social Security Administration through the Michigan Retirement Research Center (Grant \# 10-M-98362-5-01). The findings and conclusions expressed are solely those of the author and do not represent the views of the Social Security Administration, any agency of the Federal government, or the Michigan Retirement Research Center.

Regents of the University of Michigan

Julia Donovan Darrow, Ann Arbor; Laurence B. Deitch, Bingham Farms; Denise Ilitch, Birmingham; Olivia P. Maynard, Goodrich; Andrea Fischer Newman, Ann Arbor; Andrew C. Richner, Grosse Pointe Park; S. Martin Taylor, Gross Pointe Farms; Katherine E. White, Ann Arbor; Mary Sue Coleman, ex officio 


\title{
The Efficiency of Pension Menus and Individual Portfolio Choice in 401(k) Pensions
}

\begin{abstract}
Though millions of US workers have 401(k) plans, few studies evaluate participant investment performance. Using data on over 1,000 401(k) plans and their participants, we identify key portfolio investment inefficiencies and attribute them to offered investment menus versus individual portfolio choices. We show that the vast majority of 401(k) plans offers reasonable investment menus. Nevertheless, participants "undo" the efficient menu and make substantial mistakes: in a 20-year career it will reduce retirement wealth by one-fifth, in fact, more than what a naive allocation strategy would yield. We outline implications for plan sponsors and participants seeking to enhance portfolio efficiency: don't just offer or choose more funds, but help people invest smarter.
\end{abstract}

\section{Authors' Acknowledgements}

The authors thank Takeshi Yamaguchi, Raimond Maurer, Theo Nijman and Susan Thorp for under restricted access conditions; and to the Pension Research Council at the Wharton School and Vanguard for research support. This research is part of the NBER programs on Aging and Labor Economics. Opinions expressed herein are those of the authors alone, and not those of The Wharton School, Vanguard, or any other institution with which the authors may be affiliated. (C)2009 Tang, Mitchell, Mottola, and Utkus. 


\title{
The Efficiency of Pension Menus and Individual Portfolio Choice in 401(k) Pensions
}

\author{
Ning Tang, Olivia S. Mitchell, Gary Mottola, and Steve Utkus
}

In the US, 401(k) plans now represent the majority of tax-deferred company-based retirement saving programs. Almost 50 million active participants hold assets worth over \$2 trillion in these plans (as of 2008; Investment Company Institute, 2009), and 401(k) plans will increasingly represent the primary source of retirement funding for a substantial fraction of retirees (Poterba, Venti and Wise 2007). Accordingly, it is important to explore what options are commonly offered and chosen in 401(k) plans today, to help plan sponsors evaluate plan menus and also to assess portfolio choices made by participants.

How individual pension portfolios perform depends on two factors: the menu designed by plan sponsors, and the portfolio elections made by participants. In the US, plan sponsors are required by the 1974 Employee Retirement Income Security Act to offer their employees investment options with 'appropriate risk and return' features, and also to monitor these options to ensure that they continue to be appropriate. Notwithstanding recent interest in plan design, there is little evidence on whether the menus offered are efficient. Two older studies suggested that some employers offer unduly restrictive investment choice sets which could depress returns and undermine the chances that employees can actually achieve market tangency portfolios with the best Sharpe ratios. For instance, Elton, Gruber, and Blake (hereafter EGB, 2006) examine 417 smaller plans surveyed by Moody’s Investor Service in 2001; after reviewing the menus, they concluded that participants in those plans would have 53 percent less terminal wealth after two decades, compared to having held a market portfolio. A second study focused on only a subset of TIAA-CREF funds offered by employer plans in the higher education sector; that article claimed that, over a 40-year period, a participant in these plans might forgo over half their final wealth compared to an expanded menu (Angus, Brown, Smith, and Smith 2007). Nevertheless, in recent years, plan sponsors have greatly expanded the range of choices offered in 401(k) investment menus, so it is essential to revisit the question of menu choice and participant behavior using a larger and more recent dataset. 
Even if plan menus were designed to offer participants the range of market instruments, the fact remains that workers are responsible for selecting their own portfolios from the menu offered. Some prior studies have found that individual investors in 401(k) plans seem to follow a naive allocation strategy (Benartzi and Thaler, 2001; Agnew, 2002); exhibiting inertia in asset allocation (Ameriks and Zeldes, 2004; Agnew, Balduzzi, and Sunden, 2003); showing framing effects (Karlsson, Massa, and Simonov, 2007); displaying low levels of financial literacy and investment savvy (Hancock, 2002, Lusardi and Mitchell, 2007; Van Rooij, Kool and Prast, 2007); overinvesting in company stock (Liang and Weisbenner, 2002; Huberman and Sengmueller, 2004); and following their peers (Duflo and Saez, 2002). Yet these studies do not directly address the question of whether participants are doing as well as they can, given the investment menus offered. In our own previous work, we assessed the performance of 401(k) trading behavior (Yamaguchi, Mitchell, Mottola, and Utkus 2006) using risk-adjusted returns; EGB (2007) also compared the Sharpe ratios and excess risk-adjusted returns of portfolios formed by participant investment weights, with alternative portfolios formed by a naive $(1 / \mathrm{N})$ allocation strategy. But no prior study has compared the losses that might be attributable to inefficient menu offerings versus those due to poor individual investment choices. This is the task we undertake in the present paper.

To preview our findings, we show that the overwhelming majority of 401(k) plans examined do offer efficient investment menus, compared to market benchmarks. Furthermore, a savvy investor can do quite well in terms of mean-variance efficiency and diversification. Nevertheless, real-world participants fall down, since even in an efficient plan, they fail to invest and diversify well enough, as measured by return losses and idiosyncratic risk shares. These mistakes mount up, accounting for over three-quarters of the total losses sustained in an average portfolio. Indeed, actual investment patterns yield even worse results than what would be obtained using a naive allocation strategy. Finally, we show that, instead of simply adding funds to a plan menu, it is preferable to design a smarter menu and get participants to select the right set of fund choices.

The rest of the paper proceeds as follows. After describing the data, we turn to an assessment of both plan and individual portfolio efficiency. Next we investigate factors that influence portfolio performance and plan efficiency. A final section summarizes and concludes. 


\section{Empirical Setting}

The information we use is collected from 401(k) plans managed by the Vanguard mutual fund company, on behalf of a wide range of plan sponsors; here we use information on both plans and individual participants. Plan-level data include both the number and type of investment choices offered, total assets under management, numbers of accounts, ${ }^{1}$ plan type, ${ }^{2}$ and the monthly total return for each fund (12/97-12/04). ${ }^{3}$ Participant data include information on active ${ }^{4}$ accounts including account balances and amounts held by fund, source (employer or employee contributions), and participant sociodemographics (age, sex, plan tenure, non-retirement financial wealth, household income, ${ }^{5}$ homeownership status, and whether the participant had web access $^{6}$ ). Here we focus on 986,949 members of 1,003 plans as of 12/2004; each plan has at least 60 monthly return observations for every fund included in the menu.

Turning first to plan menus, the distribution of funds offered appears in Figure 1. There is a spread in the number of funds offered (3 to 59) but most plans concentrate around the mean of 13. Our figures are consistent with the mean of 14 reported by Brown, Liang and Weisbenner (using 2002 data; 2007); ${ }^{7}$ in 2004, the Profit-sharing/401(k) Council of America found that the average number of funds was around $17-18 .{ }^{8}$ For this reason, we believe that our sample is reasonably representative of the environment. Table 1 indicates the percentage of plans offering different types of funds. Overall, plan offerings are well diversified 99 percent offer fixed income/ money market funds, 97 percent have bond funds, 97 percent have balanced funds, and almost all offer equity funds. It is also worth noting the high percentage of plans offering international funds (93 percent) and low percentage of plans offering company stock options (11 percent).

Figure 1 and Table 1 here

Summary statistics on the plan characteristics appear in Table 2. Plan assets average $\$ 73$ million, with an average of 1,222 participants per plan. Domestic equity funds dominate the menus, with an average share of 19 percent in index funds and up to 28 percent in actively managed (AM) funds; also funds include (in decreasing order): AM balanced funds, money market funds, AM international equity funds, index bond funds, $A M$ bond funds, index international equity funds, index balanced funds and other funds.

Table 2 here 
Prior research has suggested that, as plans added funds over the years, the fraction of equity options has grown and most of the newly-added funds have been actively-managed (Brown, Liang, and Weisbenner 2007). This could potentially be costly to participants if the index funds were less expensive and outperformed high-cost actively managed funds. In Figure 2 we array the funds in our sample according to the number of menu options. It is clear that, as the total number of funds rises, domestic equity funds do indeed become more prevalent. In addition, actively managed funds are more prevalent than index funds, when more choices are offered; and domestic equity dominates in both AM funds and index funds.

Figure 2 here

Table 3 provides an overview of plan participant features as well as their individual portfolios. ${ }^{9}$ Panel A reports demographic characteristics, where we see that the mean participant is 45 years old; two-thirds are male; and annual household incomes average about $\$ 86,000$. Nonretirement wealth amounts to about $\$ 42,000$; most participants (96 percent) own a home; and almost half (45 percent) of them have web access. Panel B summarizes participant portfolios and indicates that the mean $401(\mathrm{k})$ plan balance is $\$ 63,000$, a balance comparable to the Investment Company Institute's (2008) data where the average age was 44 years old and the mean account balance about $\$ 65,000$. On average, participants select 3.7 funds per person and have 88 percent of their balances invested in risky assets (with the remainder mostly in index funds). ${ }^{10}$

\section{Table 3 here}

Individual fund choices appear in Figure 3. There is a notable correlation between the fund options offered and selected. This may be due to the "naive allocation" patterns documented by Benartzi and Thaler (2001) and Agnew (2002), who argued that people simply divide their money equally across all investment choices $(1 / \mathrm{N})$. Alternatively, plan sponsors may be offering the investment options that participants demand. There is also some evidence of overinvestment in company stock: that is, there is a much higher share of company stock chosen than offered. It is also worth noting that domestic equity funds and AM balanced funds dominate individual portfolios. Lastly, participants are more likely to choose actively managed instead of index funds except in the case of bonds. This may be partly due to the recent growth of actively managed balanced funds.

Figure 3 here 
Overall, these findings are comparable to larger fund universe. Thus equity funds here account for 53 percent of the assets; bond funds 8 percent; company stock 9 percent; money and GIC funds 12 percent; and non-lifecycle balanced funds 3 percent. By comparison, the Investment Company Institute (2008) showed that in 2004, participant assets were invested similarly, with fund allocations to equity at 46 percent, bonds 10 percent, company stock 15 percent, money and GIC funds 16 percent, and balanced funds 8 percent.

\section{Testing for Menu Efficiency}

In this section we test for plan menu efficiency by comparing available menus to market benchmarks, using the intersection test developed by DeRoon, Nijman and Werker (2001). This test classifies plans as either efficient or not, but does not indicate how far from efficient any given plan might be. Accordingly, we also use two additional performance measures classify plan menus: these are the plan-specific relative Sharpe ratio loss, and the idiosyncratic risk share (used by Calvet, Campbell and Sodini, 2006 to investigate the efficiency of Swedish households' investment decisions).

Efficiency Test. To test whether the investment choices offered in DC plans are efficient, we must ascertain whether one could improve the performance of the tangency portfolio (optimal linear combination) of funds held by a plan, by adding additional investment options excluded from the plan's menu. This requires constructing a set of investment choices sufficient to capture the return-risk characteristics of market investment opportunities. As in EGB (2006), we construct a "market benchmark" composed of eight commonly-accepted financial market indexes: four are domestic equity indexes following the Fama-French classification (Russell 1000 growth, Russell 1000 value, Russell 2000 growth, and Russell 2000 value); ${ }^{11}$ the two domestic bond indexes are the Lehman Aggregate and Credit Suisse First Boston High Yield. ${ }^{12}$ We also use one international equity index MSCI EAFE and one international bond index JP Morgan Global Government Bond Non-US\$. Finally, the one-month T-bill is taken as risk-free interest rate. ${ }^{13}$

We evaluate whether adding any of the eight market benchmark indexes to each plan's tangency portfolio of funds would significantly improve the portfolio return at a given level of risk. Under this test, there are short sale constraints for both funds in a plan and market benchmark index. Specifically, for each plan, we run the regression: 


$$
r_{i, t}=\alpha_{i}+\beta_{i} R_{t}+\varepsilon_{i, t}
$$

where $r_{i, t}$ is the excess return of the ith benchmark index $(\mathrm{i}=1,2 \ldots 8), R_{t}$ refers to excess returns of subset of funds held by a plan where short-sale constraints are not binding, ${ }^{14}$ and $\alpha_{i}$ is the Jensen's alpha from regression on ith benchmark index. We also test whether $\alpha_{i} \leq 0 \forall i$ for each plan. As short-sales are not allowed for market benchmark index, if none of the $\alpha_{i}$ are statistically significant positive, we could conclude that performance of funds under the plan $R_{t}$ cannot be improved by holding a long position in any of the eight market benchmark indexes. The specific test statistic is:

$$
\xi=\min _{\{\alpha \leq 0\}}(\hat{\alpha}-\alpha)^{\prime} \operatorname{Var}[\hat{\alpha}]^{-1}(\hat{\alpha}-\alpha)
$$

where $\hat{\alpha}$ is an $8 * 1$ vector of estimated Jensen's alphas. For the critical value used in the test, we adopt the lower/upper bounds suggested by Kodde and Palm (1986) and run 1000 simulations to see if the test statistic falls within the critical value bounds.

Our results indicate that 94 percent, or 940 of the 1,003 plans studied, are efficient compared to market benchmarks, by the efficiency criterion described above. This implies that 401(k) plan participants can do as well as if they were investing in the capital market at large, by choosing an optimal portfolio in their efficient 401(k) plans. It is important to point out that even plans with few choices on the menu can still be as efficient as the benchmark. Inasmuch as mutual funds can span a combination of two or more market benchmark indexes, even few investment offerings can serve participants well - as long as the choices offered are sensible ones. We explore this point further in next section.

Our finding of virtual complete 401(k) plan menu efficiency differs from the less positive finding in EGB's (2006) older study. Several factors may account for this difference. First, the EGB sample plans are far less diversified than are ours: for instance, only 71 percent plans in the EGB sample offered domestic bond funds, 81 percent plans had domestic mix (balanced) funds, 75 percent plans had international funds, and 87 percent had interest-only (money market) funds. Our set of plans is much more diverse, as indicated in Table 1. Second, our plans are far likely to offer bond funds (71 percent in EGB vs. 97 percent in our sample), which also enhances plan efficiency. Third, our data are taken from plans offered at the end of 2004, while the EGB data 
were drawn from 2001. The recent rapid growth in the mutual fund market may explain their better menus today.

Relative Sharpe Ratio Loss. We also compute the relative Sharpe ratio loss (RSRL) which compares the Sharpe ratio of a given portfolio with that of a benchmark portfolio. This measures the extent of economic loss from holding an inefficient portfolio in the mean-variance framework (Calvet, Campbell and Sodini 2006). In our case, the portfolio to be measured is the tangency portfolio of funds under each plan. The benchmark portfolio is the tangency portfolio formed by the eight market benchmark indexes introduced in earlier. Thus for portfolio p, the relative Sharpe ratio loss is defined as: $R S R L_{p}=1-\frac{S_{p}}{S_{B}} \quad$ (3), where $S_{p}=\frac{\hat{\mu}_{p}}{\hat{\Sigma}_{p}}$ is the Sharpe ratio of tangency portfolio of funds held under the plan; ${ }^{15}$ the moments of the plan are estimated by the capital asset pricing model (CAPM; see the Appendix for details); and $S_{B}$ is the Sharpe ratio of tangency portfolio of eight benchmark indexes used in the efficiency test. The moments of the eight indexes are also estimated using CAPM. From equation (3), we can see that the lower the ratio, the closer are the two Sharpe ratios; in other words, this implies a better plan performance relative to the benchmark portfolio.

The first row of Table 4 provides the distribution of relative Sharpe ratio losses of the tangency portfolio formed by available funds in each plan. Overall, the 401(k) plans in our analysis sample perform very well compared to the benchmark portfolio: the mean relative Sharpe ratio loss of 0.03 is quite low. In other words, the Sharpe ratio of the tangency portfolio of an average plan is 97 percent of that of the benchmark portfolio. Furthermore, the sample plans vary little in terms of their relative Sharpe ratio losses: even at the 90th percentile, the measure is only 0.05 . A small residual of plans does not perform very well, which boosts the $99^{\text {th }}$ percentile of the measure to 0.66 .

\section{Table 4 here}

Idiosyncratic Risk Share. Next we examine idiosyncratic risk share measures, or the share of portfolio total variance attributable to idiosyncratic risk out. Idiosyncratic risk is defined as the risk that can be diversified away; therefore it measures a portfolio's undiversified risk (Calvet, Campbell and Sodini, 2006). Specifically: $\operatorname{IRS} S_{p}=\frac{\hat{\Sigma}_{i d i o, p}}{\hat{\Sigma}_{p}}$ (4), where $\hat{\Sigma}_{i d i o, p}$ is the idiosyncratic 
risk of tangency portfolio of funds held by the plan, and $\hat{\Sigma}_{p}$ is the total risk of the tangency portfolio. So the lower the ratio, the better is the performance of a given plan.

The distribution of idiosyncratic risk share across our sample is displayed in the second row of Table 4. On average, the idiosyncratic risk is 0.03 ; in other words, only 3 percent of the total variance of plan's tangency portfolio is not diversified away. Even at the $90^{\text {th }}$ percentile, the ratio is still below 0.08, which indicates a high diversification level. It is interesting that a handful, around 1 percent of the plans, does not perform well according to this measure, having an idiosyncratic risk share of over 0.21 .

We can also compare performance measures for efficient and inefficient plans. Here results show that there is little difference in the two performance measures between efficient and inefficient plans (relative Sharpe ratio losses are 0.04 vs. 0.03 , and idiosyncratic risk shares are 0.05 vs. 0.03 for inefficient and efficient plans respectively). This suggests that even inefficient plans in our sample are not far from offering efficient menu selections. In sum, we conclude that the plan menus offered in this sample are quite efficient in terms of mean-variance efficiency and diversification level. Even the few inefficient plans are not performing terribly, and there is little evidence of plan menu design inefficiency.

\section{Testing for Individual Investment Efficiency}

Next we assess the efficiency of individual participants' investment efficiency given the plan menus offered. Three measures are used. The first is the total return loss, which captures the investor's return shortfall from what he could have optimally obtained from the capital market, given his preferred level of investment risk. It is an overall evaluation on total losses of participants' portfolio caused by both participant investment choice inefficiency and plan menu inefficiency. The second measure is the relative return loss, which captures the investor's return shortfall from what he could have optimally obtained from the plan offered, instead of the capital market in total return loss measure. Such a measure excludes any inefficiency resulting from menu restrictions, thus successfully distinguishing participant investment mistakes from the inefficiency due to menu design. The third measure is the idiosyncratic risk share. As documented by Poterba, Venti and Wise (2007) and EGB (2006), retirement accounts are the sole source of retirement funding for a substantial fraction of people. Accordingly, whether the 
actual portfolios selected exhibit proper diversification is important in evaluating portfolio performance.

Total Return Loss. The concept of "return loss" speaks to the return shortfall experienced by a participant's actual portfolio, given his choice of risk level, compared to the highest return that he could have been achieved in the broader capital market (Calvet, Campbell, and Sodini, 2006). Assume that a participant in plan $j$ chooses a portfolio $p$ with risk level $\sigma_{p}$. The monthly total return loss for his portfolio is: $R L_{p}=w_{p}\left(\mu_{B}-\mu_{p}\right)(6)$, where $\mu_{B}$ is the best return that could be optimally attained at risk level $\sigma_{p}$, with the eight market benchmark indexes which represent the capital market investment opportunities mentioned earlier; and $\mu_{p}$ is the actual return of the participant's portfolio for the same risk level $\sigma_{p}$. The term $w_{p}$ refers to the risk share, which is calculated using the balance amount in each individual participant's portfolio. This weight multiplier permits the measure to reflect the fact that participants holding poorly performing risky assets might still be close to the efficient frontier if they their risky exposure is small. The total return loss before weight adjustment is demonstrated by the line segment $\mathrm{A}$ in Figure 4, where $\left(\mu_{p}, \sigma_{p}\right)$ is the actual portfolio chosen by the participant, and the outer curve is the efficient frontier formed by the eight market benchmark indexes.

Figure 4 here

The first panel in Figure 5 shows the distribution of the monthly total return loss for 986,949 individual portfolios in 1,003 plans (as of 12/04). The mean total return loss is a monthly 0.1093 percent; again there is a distribution around this mean, with 3 percent of the participants having a return loss of zero and 1 percent of participants having a total return loss of over 0.4 percent per month. To put these results into context, if assume a participant could earn a monthly return of 0.5 percent, ${ }^{16}$ he could be expected to enhance his retirement wealth by 30 percent over a 20 -year holding period by moving to the efficient frontier. ${ }^{17}$ Additionally, under the same assumption, those in the largest one percentile of the return loss distribution could lose up to 160 percent in retirement wealth over a 20-year period. ${ }^{18}$ Accordingly, plan participants forgo a substantial component of retirement accruals by not investing optimally.

Figure 5 here 
Relative Return Loss. The total return loss above measures the total loss due to both participant investment choice inefficiency and plan menu restrictions. To distinguish between these sources of inefficiency, we next calculate the relative return loss which reflects only the inefficiency resulting from poor participant investment choices given plan menus. We do so by computing the best return obtainable in plan $j$ for risk level $\sigma_{p}$ or is $\mu_{B}$ in equation (5), keeping all other factors constant. That is, we calculate the return shortfall of each actual individual portfolio compared to the best return that could be obtained in the same plan for the same risk level. Thus line segment $\mathrm{B}$ in Figure 4 reflects the relative return loss before weight adjustment $w_{p}$ in equation (6), where the interior curve is the efficient frontier formed by funds available in a plan. The distance between segments A and B measures the inefficiency caused by menu restrictions.

The second graph in Figure 5 reports the distribution of monthly relative return losses for the same participants; here we see that these losses are concentrated around a monthly mean loss of 0.079 percent. This monthly relative return loss would imply 21 percent less retirement wealth after a 20-year period. Again there is a distribution: some 6 percent of the participants have a return loss of zero, but 1 percent of participants experience a return loss of over 0.29 percent per month. Thus we conclude that few plan participants actually select an optimal portfolio from the menu offered to them, and a subset will lose a great deal, having failed to make wise investment choices. On average, the relative return loss from participant investment mistakes accounts for three quarters (76 percent) of the total return loss, indicating that participant portfolio choice inefficiency is the main source of underperformance.

Idiosyncratic Risk Share. Next we turn examine the idiosyncratic risk share of an individual's portfolio, defined as the ratio of idiosyncratic risk to the portfolio's total variance. Figure 6 displays the distribution of this measure, and it shows that the mean value of the idiosyncratic risk share is 0.187 , a value much higher than the level that could be optimally achieved in a plan (it has a mean of 0.03 as shown in Table 4). Again there is a wide range from 0.001 to 0.997; also the top 5 percent of participants has an idiosyncratic risk share of more than 0.77 , meaning that 77 percent of the portfolio variance is not rewarded by higher expected return. In other words, the idiosyncratic risk share evidence indicates that participants do not satisfactorily diversify their 401(k) plan portfolios.

Figure 6 here 
Actual Portfolio vs. Naive Allocation Strategy. Because of this opportunity to evaluate actual participant portfolios, we can also determine whether participants do better than simply following a naive allocation strategy such as the simple " $1 / \mathrm{N}$ " approach described above, which equally weights all funds offered (Benartzi and Thaler, 2001; Agnew, 2002). To do so, we evaluate the relative return loss and idiosyncratic risk share of a hypothetical participant in each plan who follows a naive allocation strategy and compare it to the actuals just described. Results appear in Figure 7, which confirm that actual individual portfolios underperform even the naive allocation strategy: they have higher relative return losses ( 0.079 percent vs.0.076 percent) and much higher idiosyncratic risk shares (0.187 vs. 0.04). This reinforces our conclusion that participants do not invest as efficiently as they could in their 401(k) plans.

Figure 7 here

\section{Determinants of Portfolio Efficiency: Behavioral and Plan Menu Effects}

Having detected substantial inefficiencies in individual portfolio choice patterns, it is of use to inquire how investment performance might be enhanced. Two clear paths are available to improve 401(k) individual portfolio performance: by getting individual participants to alter their portfolio choices, or by altering plan sponsor menus. Specifically, we examine factors contributing to the variation in portfolio performance across participants and plans, and we further explore what characteristics contribute to plan menu efficiency. In particular, we seek to learn whether simply adding more funds, as most plan sponsors are doing today, is likely to boost plan efficiency.

Individual Portfolio Choice Effects. Given the wide range of menu options available to 401(k) investors, it is useful to check what kinds of funds are most likely to boost participant outcomes. Prior studies have shown that actively managed funds underperform index funds (Brown, Liang and Weisbenner, 2007), but that work did not evaluate actual participant portfolio performance. We fill this gap by investigating whether there are significant differences between index versus actively managed funds, using the following multivariate regression function:

$$
\text { Perform }_{i, j}=\alpha+\beta_{1} \text { Invest }_{i, j}+\beta_{2} \text { Demo }_{i, j}+\beta_{3} \text { Plan }_{j}+\varepsilon_{i, j}
$$

where $\mathrm{i}$ refers to the individual participant, and $\mathrm{j}$ refers to the plan. Dependent variables Perform $_{i, j}$ refer to the portfolio relative return losses as well as idiosyncratic risk share 
calculated previously. Invest $t_{i, j}$ refers to a vector of individual investment characteristics including the number of funds chosen, company stock share and shares of eight types of funds: index bond, actively managed bond, index balanced, actively managed balanced, index domestic equity, actively managed domestic equity, index international equity, and actively managed international equity. Demo $_{i, j}$ refers to individual demographic characteristics such as the participant's age, income, non-retirement wealth, and web access. Plan ${ }_{j}$ refers to a vector of plan-specific characteristics which affect Perform $_{i, j}$ and are common among all participants in the same plan.

To eliminate unobserved plan fixed effects, Plan $_{j}$, we transformation the data as follows:

$$
\left(\text { Perform }_{i, j}-{\overline{\text { Perform }_{j}}}_{j}\right)=\alpha+\beta_{1}\left(\text { Invest }_{i, j}-{\overline{\text { Invest }_{j}}}\right)+\beta_{2}\left(\text { Demo }_{i, j}-{\overline{\text { Demo }_{j}}}\right)+\varepsilon_{i, j}
$$

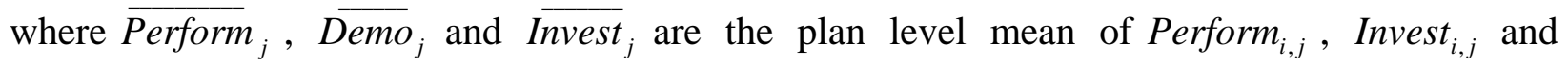
Demo $_{i, j}$ respectively. Table 5 shows results of estimating equation (7); dependent variables in the two columns are, respectively, relative return losses in percentage, and idiosyncratic risk share. The results show that choosing more funds does not much curtail return losses, although it can improve portfolio diversification. Inasmuch as most 401(k) assets are mutual funds (funds of assets), it is possible that a single mutual fund could span the portfolio formed by several individual assets. For this reason, participants should not strive to diversity across all funds in the portfolio for its own sake. Second, all the funds, except for international equity actively managed and balanced equity index funds, outperform the domestic equity index funds in terms of return losses. Bond funds help to improve the performance most. This means that in addition to holding domestic equity funds like most participants do today, holding bond funds, also make sense. Third, index domestic funds improve portfolio diversification level most, so they are good choices in terms of portfolio diversification. Fourth, index funds do not dominate actively managed funds in every respect: although index funds help improve portfolio diversification more than do actively managed funds (except international equity funds), they do not persistently outperform actively managed funds in terms of return loss.

Table 5 here 
Finally, we find that younger and more financially sophisticated with web access or higher income participants or those with more non-retirement wealth have lower return losses. In addition, the younger people and people with more non-retirement wealth, but less income and no web access, have more diversified portfolios. These results are consistent with Calvet, Campbell and Sodini (2006) who show that richer people choose more diversified portfolios while older people do not, but we differ in that Sweden that richer and more educated Swedish households bear higher costs from portfolio inefficiency as measured by return loss. This might be due to differences in financial literacy between Swedish and US 401(k) households.

In sum, we conclude that participants do try to diversify their portfolios, but this does not insure they end up with an efficient portfolio mix inside their 401(k) plans.

Menu Effects. To determine what menu design factors might influence plan efficiency, next we run regressions of the form:

$$
\text { Perform }_{j}=\alpha+\beta_{1} \text { PLANCOMP }_{j}+\beta_{2} \text { PLANCHAR }_{j}+\beta_{3} \text { PRTCHAR }_{i, j}+\varepsilon \text { (9), }
$$

where the dependent variable Perform $_{j}$ is a vector of outcomes indicating performance measures for the plans described earlier. A first dependent variable is a $(0,1)$ indicator which takes on the value of 1 if the plan is efficient ( 0 if not); we also examine patterns for the relative Sharpe ratio loss and idiosyncratic risk share, respectively. The explanatory variable PLANCOMP represents a vector of plan characteristics including the number of options offered and the availability of different types of funds. ${ }^{19} \mathrm{~A}$ second vector of explanatory variables PLANCHAR is used to control for plan characteristics such as plan size (measured by ln accounts, ln 401(k) plan assets, ${ }^{20}$ and contribution source). We also control on PRTCHAR which captures participant characteristics such as age, sex, plan tenure, and income as well as asset indicators - some of which are correlated with financial sophistication (ln non-retirement financial wealth, ln household income, home ownership, and web access).

Table 6 shows the results of these multivariate models, where the first is a Probit regression on plan efficiency, and the other two are OLS regressions on the relative Sharpe ratio loss and idiosyncratic risk share. The evidence suggests that simply having more funds on the menu does not improve plan efficiency, although it can curtail the relative Sharpe ratio loss and idiosyncratic risk share. The magnitudes are small compared to the effect of other factors such as availability of certain funds. For example, the "number of funds" variable has a negative 
coefficient of -0.004 , the magnitude of which is much lower than the coefficient on availability of index and actively managed bond funds $(-0.13$ and -0.05$)$. The marginal benefit from adding more options is also decreasing, as indicated by the concave relationship between the number of options and plan performance. This is a striking finding, especially considering the current trend of plan sponsors to expand plan menus seeking to better serve participants. Since a single mutual fund contains different assets, having even a handful of these in the menu can achieve substantial diversification. Accordingly, plan sponsors should not merely load more funds onto the menu in the hopes of increasing plan efficiency.

The conclusion is further confirmed by Figure $8 .{ }^{21}$ It shows the average relative Sharpe ratio loss and idiosyncratic risk share calculated earlier, for plans arrayed by the number of funds they offer in their menus. Overall, the two measures are very low, indicating good plan performance. When a plan has more than nine funds, the measure becomes quite stable. Thus adding more funds does not improve the relative Sharpe ratio loss or idiosyncratic risk share much after this point.

\section{Table 6 and Figure 8 here}

In Table 6, we also find that specific kinds of funds have the largest positive effect in improving menu efficiency. Including index bond funds, for instance, is beneficial for efficiency; conversely, balanced and actively managed international equity funds hurt plan efficiency during this period. Last, we find that adding index domestic equity funds also improves plan efficiency, not the case for actively managed domestic equity funds.

Considering the economic cost of adding more funds and the potential loss participants might bear from facing complicated menus, it may be better for plan sponsors to devote attention to fund selection, to enhance influence plan performance. Previously we noted that plan sponsors have increased the number of actively managed domestic equity funds over time, but our evidence suggests that this should not be done in the name of plan efficiency. And it is better to add funds that make the menu more efficient, rather than simply making the menu longer.

\section{Conclusions and Implications}

We have used a rich new dataset to explore what options are commonly offered and elected in modern US $401(\mathrm{k})$ plans, with the goal of evaluating investment menus offered by plan sponsors and portfolio choices selected by participants. We also seek to identify 
determinants of portfolio efficiency and to outline what can be done to enhance it. On the positive side, virtually all the plans we examine are efficient compared to the benchmark; this means that the plan sponsors can be applauded for offering sensible menus in terms of meanvariance efficiency and diversification. On the negative side, we find that participants err by investing inefficiently and not diversifying enough. Such mistakes can be important, producing one-fifth less retirement wealth in a 20-year period. Participants' failure to pick the best portfolio from the investment options offered to them account for the bulk of their poor performance. Therefore this offers room for better-designed default options which employees might be moved into in an autoenrollment framework (Mitchell, Mottola, Utkus and Yamaguchi, 2009).

Although we focus here mainly on behavior in individual retirement accounts, our research has implications for portfolio choice and wealth outcomes more generally. Today almost half of all Americans have at least some assets in a tax-deferred account, and asset allocations are quite similar inside and outside tax-deferred accounts (Bergstresser and Poterba 2004). Consequently it is likely that the inefficiencies observed in the retirement context are replicated outside the 401(k) setting. To combat participants' financial illiteracy, it may therefore be critical to provide financial education and advice regarding investment patterns. This philosophy informed the adoption of so-called 'default' investment options such as target maturity date funds under the 2006 Pension Protection Act. Better managed retirement saving requires building investor financial literacy. 


\section{References}

Agnew, Julie, Pierluigi Balduzzi, and Annika Sunden. 2003. "Portfolio Choice and Trading in a Large 401(K) Plan.” American Economic Review 93 (1), 193-215.

Agnew, Julie. 2002. “Inefficient Choices in 401(K) Plans: Evidence from Individual Level Data.” Presented at the $4^{\text {th }}$ Annual Joint Conference for the Retirement Research Consortium “Directions for Social Security Reform,” May 2002, Washington, D.C.

Ameriks, John, and Stephen P. Zeldes. 2004. "How do Household Portfolio Shares Vary with Age?” TIAA-CREF working paper.

Angus, John, William O. Brown, Janet Kiholm Smith, and Richard L. Smith. 2007. "What's in Your 403(B)? Academic Retirement Plans and the Costs of Underdiversification.” Financial Management, Summer 2007, 1-38.

Benartzi, Shlomo, and Richard H. Thaler. 2001. "Naïve Diversification Strategies in Defined Contribution Savings Plans.” American Economic Review, 91 (1), 79-98.

Bergstresser, Daniel, and James Poterba. 2004. “Asset Allocation and Asset Location: Household Evidence from the Survey of Consumer Finances.” Journal of Public Economics, 88 (9-10), 1893-1915.

Blake, Christopher R., Edwin J. Elton, and Martin J. Gruber. 1993. “The Performance of Bond Mutual Funds.” Journal of Business, 66, 371-403.

Brown, Jeffrey R., Nellie Liang, and Scott Weisbenner. 2007. "Individual Account Investment Options and Portfolio Choice: Behavioral Lessons from 401(K) Plans.” Journal of Public Economics, 91 (10), 1992 - 2013.

Calvet, Laurent E., John Y. Campbell, and Paolo Sodini. 2006. "Down or Out: Assessing the Welfare Costs of Household Investment Mistakes.” Journal of Political Economy, 115 (5), 707-747.

DeRoon, Frans A., Theo E. Nijman, and Bas J.M. Werker. 2001. “Testing for Mean-Variance Spanning with Short Sales Constraints and Transaction Costs: The Case of Emerging Markets.” Journal of Finance, 56 (2), 721-742.

Duflo, Esther, and Emmanuel Saez. 2002. "Participation and Investment Decisions in a Retirement Plan: The Influence of Colleagues’ Choices.” Journal of Public Economics, 85 (1), 212-148. 
Elton, Edwin J., Martin J. Gruber, and Christopher R. Blake. 2006. "The Adequacy of Investment Choices Offered by 401K Plans.” Journal of Public Economics, 90 (6-7), 1299-1314.

Elton, Edwin J., Martin J. Gruber, and Christopher R. Blake. 2007. "Participant Reaction and the Performance of Funds Offered by 401(K) Plans.” Journal of Financial Intermediation, 16 (2), 240-271.

Hancock, John. 2002. "Eighth Defined Contribution Plan Survey.” John Hancock Financial Services, Boston: John Hancock.

Huberman, Gur, and Paul Sengmueller. 2004. "Performance and Employer Stock in 401(K) Plans." Review of Finance, 8, 403-443.

Investment Company Institute. 2008. "401(K) Plan Asset Allocation, Account Balances, and Loan Activity in 2007.” Investment Company Institute Research Perspective, 14 (3), 2008.

Investment Company Institute. 2009. “The U.S. Retirement Market, 2008.” Investment Company Institute Research Fundamentals, 18(5), June 2009.

Karlsson, Anders, Massimo Massa, and Andrei Simonov. 2007. "Pension Portfolio Choice and Menu Exposure.” In: Madrian, Brigitte, Olivia S. Mitchell, Beth J. Soldo (eds.), Redefining Retirement: How Will Boomers Fare? Oxford: Oxford University Press, 248270.

Kodde, David A., and Franz C. Palm. 1986. "Wald Criteria for Jointly Testing Equality and Inequality Restrictions.” Econometrica, 54, 1243-1248.

Liang, Nellie, and Scott Weisbenner. 2002. "Investor Behavior and the Purchase of Company Stock in 401(K) Plans - The Importance of Plan Design.” Finance and Economics Discussion Series 2002-36. Washington: Board of Governors of the Federal Reserve System, 2002.

Lusardi, Annamaria and Olivia S. Mitchell. 2007. "Baby Boomer Retirement Security: The Roles of Planning, Financial Literacy, and Housing Wealth.” Journal of Monetary Economics. 54(1) January: 205-224.

Mitchell, Olivia S., Gary Mottola, Steve Utkus, and Takeshi Yamaguchi. 2009. "Menu Effects and Retirement Saving: The Impact of Life Cycle Funds on 401(K) Plan Portfolios.” PRC Working Paper, Presented at the 2009 ASSA meetings, San Francisco. 
Poterba, James, Steven Venti, and David Wise. 2007. "Rise of 401(K) Plans, Lifetime Earnings, and Wealth at Retirement.” NBER Working Paper No. 13091.

Van Rooij, Maarthen C.J., Clements, J.M. Kool, and Henriette M. Prast. 2007. "Risk-Return Preferences in the Pension Domain: Are People Able to Choose?” Journal of Public Economics, 91 (3-4), 701-722.

Yamaguchi, Takeshi, Olivia S. Mitchell, Gary R. Mottola, and Stephen P. Utkus. 2006. "Winners and Losers: 401(K) Trading and Portfolio Performance.” Pension Research Council Working Paper No. 2006-26, The Wharton School. 
Table 1. Percentage of Plans Offering Investment Options by Fund Type

\begin{tabular}{|c|c|c|c|}
\hline Broad category & \% of Plans offering options & "Detailed category & \% of Plans offering options \\
\hline \multirow{2}{*}{$\begin{array}{l}\text { Fixed income/ money } \\
\text { market funds }\end{array}$} & \multirow{2}{*}{99.1} & Money market & 74.6 \\
\hline & & Investment contract & 50.2 \\
\hline \multirow{2}{*}{ Bond funds } & \multirow{2}{*}{97.4} & Unfunded & 0.3 \\
\hline & & Bond & 97.4 \\
\hline Balanced funds & 96.5 & Balanced & 96.5 \\
\hline \multirow{2}{*}{ Equity funds } & \multirow{2}{*}{99.9} & Domestic & 99.9 \\
\hline & & International & 93.1 \\
\hline \multirow{2}{*}{ Other } & \multirow{2}{*}{13.1} & Brokerage option & 2.4 \\
\hline & & Company stock & 11.4 \\
\hline
\end{tabular}

Source: Authors' computations.

Note: Brokerage option permits employees to choose their own stock options; 1,003 plans. 
Table 2. Summary Statistics on Plan Menus

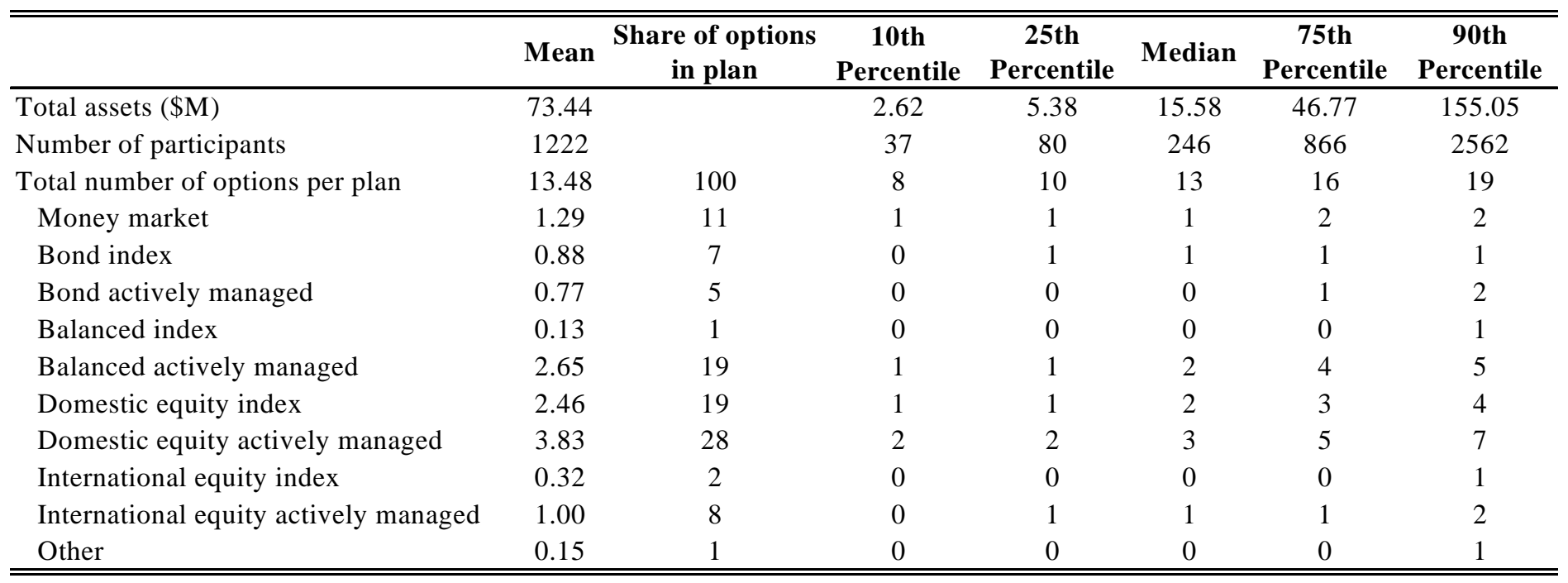

Source: Authors' computations.

Note: 1,003 plans 
Table 3. Summary Statistics on Participants.

\begin{tabular}{lcccccc}
\hline \hline & Mean & $\begin{array}{c}\text { 10th } \\
\text { Percentile }\end{array}$ & $\begin{array}{c}\text { 25th } \\
\text { Percentile }\end{array}$ & Median & $\begin{array}{c}\text { 75th } \\
\text { Percentile }\end{array}$ & $\begin{array}{c}\text { 90th } \\
\text { Percentile }\end{array}$ \\
\hline Demographic characteristics & & & & & & \\
Age & 45 & 30 & 37 & 45 & 52 & 58 \\
Male (yes=1, no=0) & 0.68 & 0 & 0 & 1 & 1 & 1 \\
Household income (\$) & 86,227 & 35,000 & 62,500 & 86,319 & 87,500 & 137,500 \\
Non-retirement wealth (\$) & 41,708 & 0 & 1,677 & 7,280 & 35,737 & 111,683 \\
Web access (yes=1, no=0) & 0.45 & 0 & 0 & 0 & 1 & 1 \\
Homeowner (yes=1, no=0) & 0.96 & 1 & 1 & 1 & 1 & 1 \\
\hline Individual portfolio characteristics & & & & & & \\
Number of funds chosen & 3.72 & 1 & 2 & 3 & 5 & 7 \\
Total balance (\$K) & 63.27 & 2.28 & 8.99 & 28.19 & 74.02 & 158.31 \\
Index share & 0.28 & 0 & 0 & 0.21 & 0.47 & 0.76 \\
Risk share & 0.88 & 0.53 & 0.85 & 1 & 1 & 1 \\
\hline \hline
\end{tabular}

Source: Authors' computation.

Note: 986,614 participants.

Table 4. Distribution of Plan Performance Measures

\begin{tabular}{|c|c|c|c|c|c|c|c|c|}
\hline & Mean & $\begin{array}{c}\text { 1st } \\
\text { Percentile }\end{array}$ & $\begin{array}{c}\text { 10th } \\
\text { Percentile }\end{array}$ & $\begin{array}{c}\text { 25th } \\
\text { Percentile }\end{array}$ & Median & $\begin{array}{c}\text { 75th } \\
\text { Percentile }\end{array}$ & $\begin{array}{c}\text { 90th } \\
\text { Percentile }\end{array}$ & $\begin{array}{c}\text { 99th } \\
\text { Percentile }\end{array}$ \\
\hline Relative Sharpe ratio loss & 0.03 & 0.003 & 0.01 & 0.01 & 0.01 & 0.01 & 0.05 & 0.66 \\
\hline Idiosyncratic risk share & 0.03 & 0.005 & 0.01 & 0.02 & 0.02 & 0.02 & 0.08 & 0.21 \\
\hline
\end{tabular}

Source: Authors' computations.

Note: $\mathrm{N}=1,003$ plans. 
Table 5. Regression of Return Loss and Idiosyncratic Risk Share on Individual Characteristics and Plan Features

\begin{tabular}{|c|c|c|c|c|c|}
\hline Dependent variables & Mean & \multicolumn{2}{|c|}{$\begin{array}{c}\text { (1) Relative return loss } \\
\text { (in \%) } \\
\text { mean=0.0794\% }\end{array}$} & \multicolumn{2}{|c|}{$\begin{array}{c}\text { (2) Idiosyncratic risk } \\
\text { share (in \%) } \\
\text { mean=18.69\% }\end{array}$} \\
\hline Investment pattern & & & & & \\
\hline Number of funds chosen & 3.72 & $0.0005 \%$ & $* * *$ & $-1.26 \%$ & $* * *$ \\
\hline Balanced index funds share (in \%) & $0.52 \%$ & $-0.000001 \%$ & & $0.02 \%$ & $* * *$ \\
\hline Balanced actively managed funds share (in \%) & $17.77 \%$ & $-0.0002 \%$ & $* * *$ & $0.16 \%$ & $* * *$ \\
\hline Bond index funds share (in \%) & $5.16 \%$ & $-0.0008 \%$ & $* * *$ & $0.11 \%$ & $* * *$ \\
\hline Bond actively managed funds share (in \%) & $2.63 \%$ & $-0.0008 \%$ & $* * *$ & $0.17 \%$ & $* * *$ \\
\hline Domestic equity actively managed funds share (in \%) & $26.61 \%$ & $-0.00004 \%$ & $* * *$ & $0.17 \%$ & $* * *$ \\
\hline International equity index funds share (in \%) & $0.49 \%$ & $-0.0003 \%$ & $* * *$ & $0.12 \%$ & $* * *$ \\
\hline International equity actively managed funds share (in \%) & $3.37 \%$ & $0.0002 \%$ & $* * *$ & $0.05 \%$ & $* * *$ \\
\hline $\begin{array}{l}\text { Company stock Share (in \%) } \\
\text { (Ref: Domestic equity index funds share) }\end{array}$ & $9.31 \%$ & $-0.0002 \%$ & $* * *$ & $0.88 \%$ & $* * *$ \\
\hline Participant characteristics & & & & & \\
\hline Age & 44.56 & $0.0001 \%$ & $* * *$ & $0.01 \%$ & $* * *$ \\
\hline Web access $(1=$ Yes, $0=$ No $)$ & 0.45 & $-0.0018 \%$ & $* * *$ & $0.15 \%$ & $* * *$ \\
\hline Ln household income (\$) & 11.18 & $-0.0001 \%$ & $*$ & $0.07 \%$ & $* * *$ \\
\hline Ln non-retirement financial wealth (\$) & 8.06 & $-0.0001 \%$ & $* * *$ & $-0.04 \%$ & $* * *$ \\
\hline R squared & & 0.2885 & & 0.6058 & \\
\hline
\end{tabular}

Source: Authors' computations.

Note: 986,614 participants. 
Table 6. Menu Effects on Plan Efficiency and Performance

\begin{tabular}{|c|c|c|c|c|c|c|c|}
\hline Dependent variables & Mean & $\begin{array}{r}\text { (1) } \\
\text { Plan efficien } \\
(1=\text { efficient, } 0 \\
\text { Mean=9 } \\
\text { Margina }\end{array}$ & $\begin{array}{l}\text { nmy } \\
\text { cient) }\end{array}$ & \multicolumn{2}{|c|}{$\begin{array}{c}\text { Relative Sharpe } \\
\text { ratio loss } \\
\text { mean }=0.03 \\
\text { OLS coefficient }\end{array}$} & \multicolumn{2}{|c|}{$\begin{array}{c}(3) \\
\text { Idiosyncratic } \\
\text { risk share } \\
\text { mean=3.25\% }\end{array}$} \\
\hline \multicolumn{8}{|l|}{ Plan components } \\
\hline Number of funds & 12 & $-0.18 \%$ & & -0.004 & $* * *$ & -0.003 & *** \\
\hline Number of funds square & 177 & $0.002 \%$ & & 0.0001 & $* * *$ & 0.0001 & *** \\
\hline Offer balanced index funds (yes $=1$, no $=0$ ) & 0.13 & $-3.68 \%$ & $*$ & 0.004 & & -0.001 & \\
\hline Balanced actively managed funds & 0.93 & $0.89 \%$ & & 0.01 & & 0.01 & ** \\
\hline Bond index funds & 0.81 & $8.00 \%$ & $* * *$ & -0.13 & $* * *$ & -0.08 & $* * *$ \\
\hline Bond actively managed funds & 0.46 & $0.22 \%$ & & -0.05 & $* * *$ & -0.01 & $* *$ \\
\hline Domestic equity index funds & 0.99 & $16.89 \%$ & $* *$ & 0.01 & & 0.01 & \\
\hline Domestic equity actively managed funds & 0.97 & $-2.30 \%$ & & 0.00 & & 0.01 & \\
\hline International equity index funds & 0.24 & $0.69 \%$ & & 0.02 & $* *$ & 0.01 & \\
\hline International equity actively managed funds & 0.84 & $-1.88 \%$ & & 0.005 & & 0.01 & $* *$ \\
\hline Company stock & 0.11 & $-2.77 \%$ & & 0.02 & & 0.01 & $*$ \\
\hline $\mathrm{R}$ squared & & 0.0426 & & 0.3035 & & 0.4769 & \\
\hline
\end{tabular}

Source: Authors' computations.

Note: 1,003 plans. 
Figure 1. Percentage of Plans Offering Various Numbers of Funds

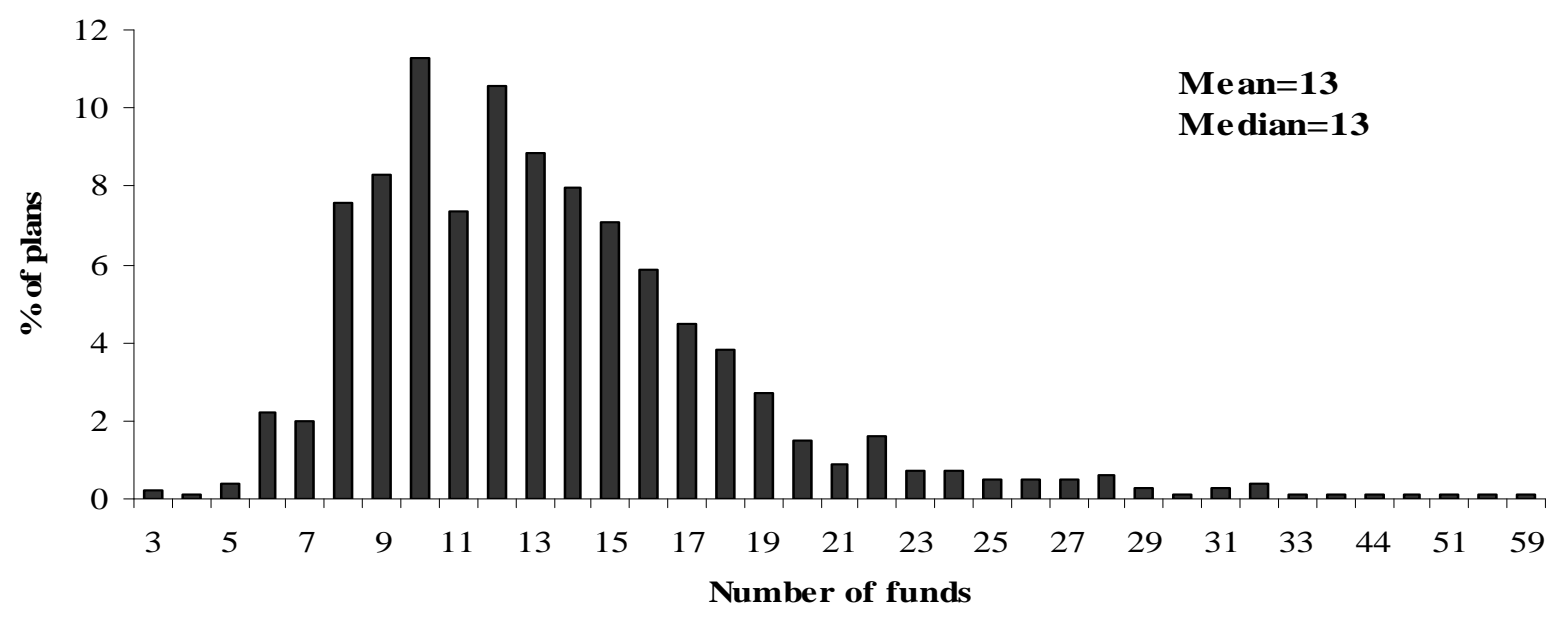

Source: Authors' computations.

Note: 1,003 plans 
Figure 2. Number of Index/ Actively Managed Funds vs. Total Number of Funds

A. Number of Index Funds by Type vs. Number of Funds Offered

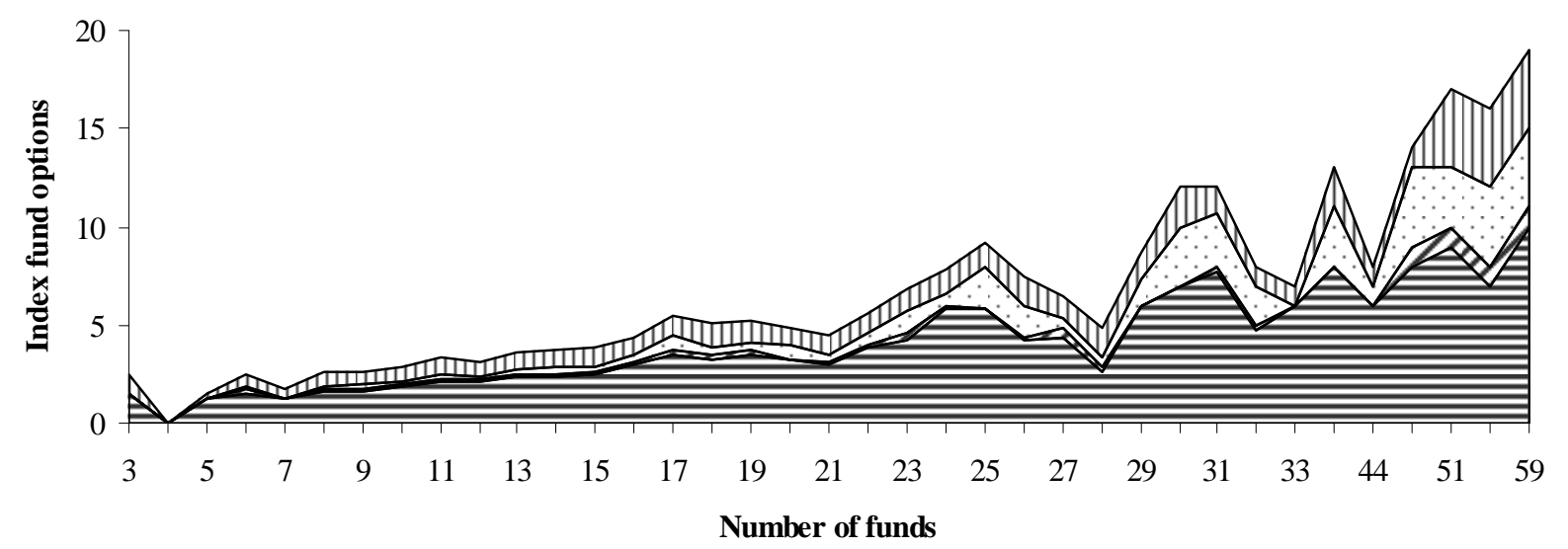

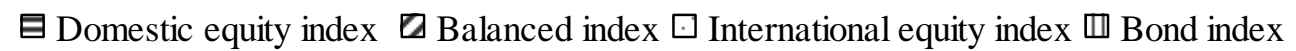

B. Number of Actively Managed (AM) Funds by Type vs. Number of Funds Offered

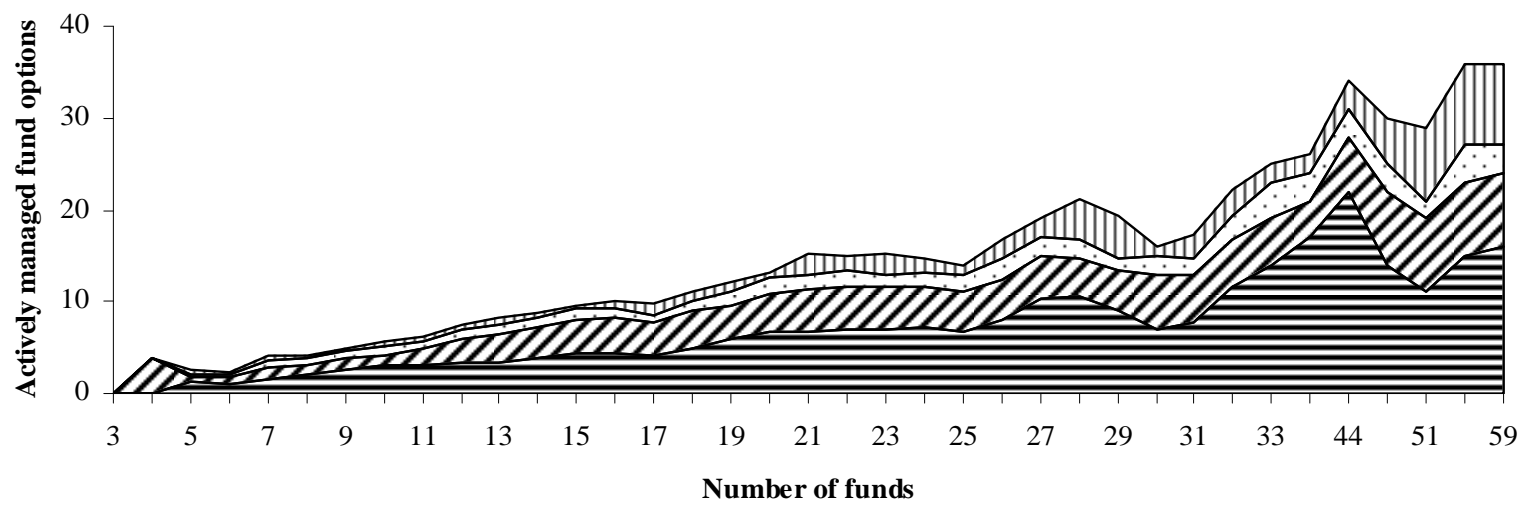

$\boxminus$ Domestic equity AM $\square$ Balanced AM $\square$ International equity AM $\square$ Bond AM

Source: Authors' computation.

Note: 1,003 plans 
Figure 3. Allocation of Individual Participants' Portfolios.

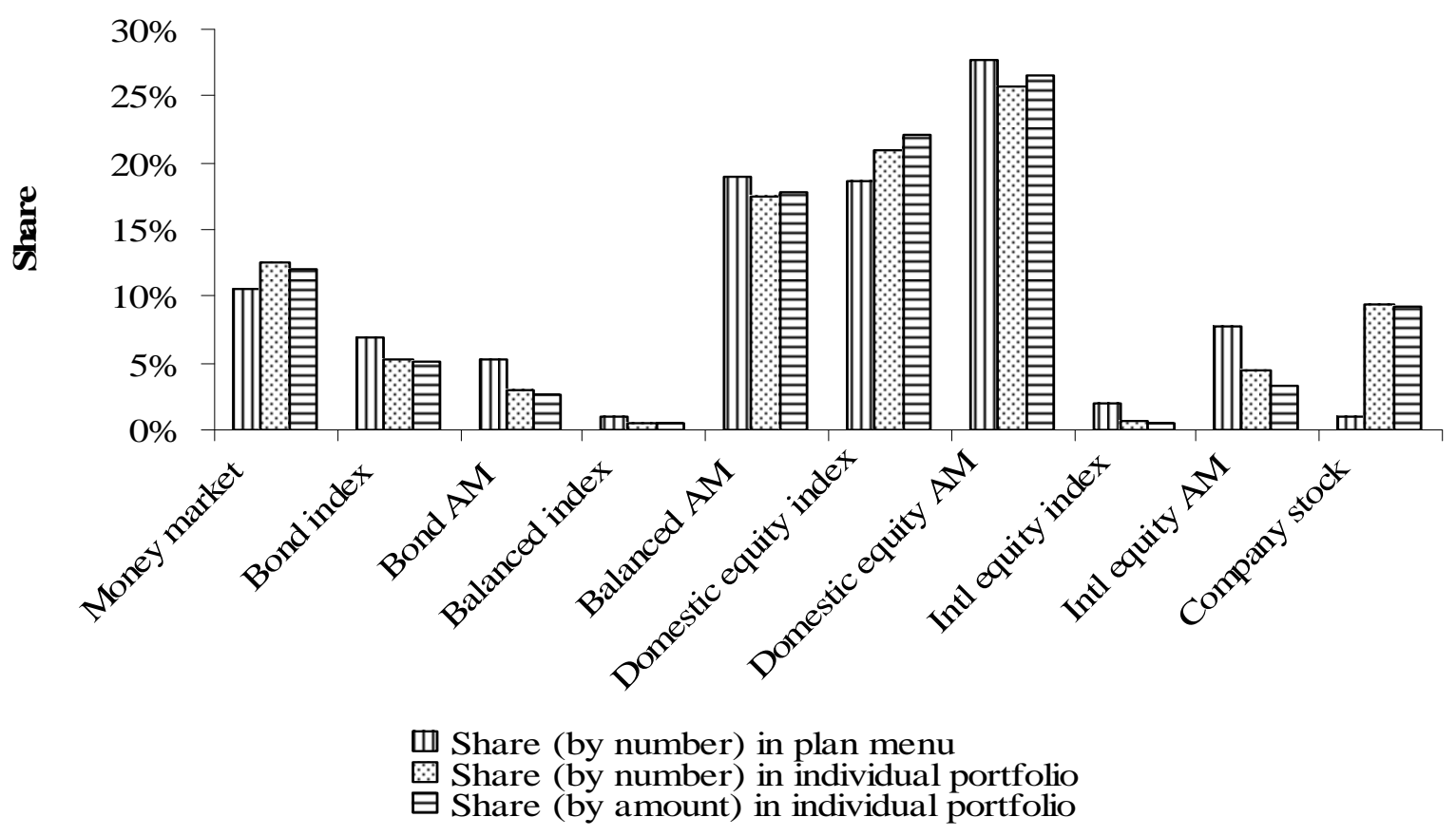

Source: Authors' computations.

Note: 1,003 plans and 986,614 participants.

Figure 4. Total and Relative Return Loss

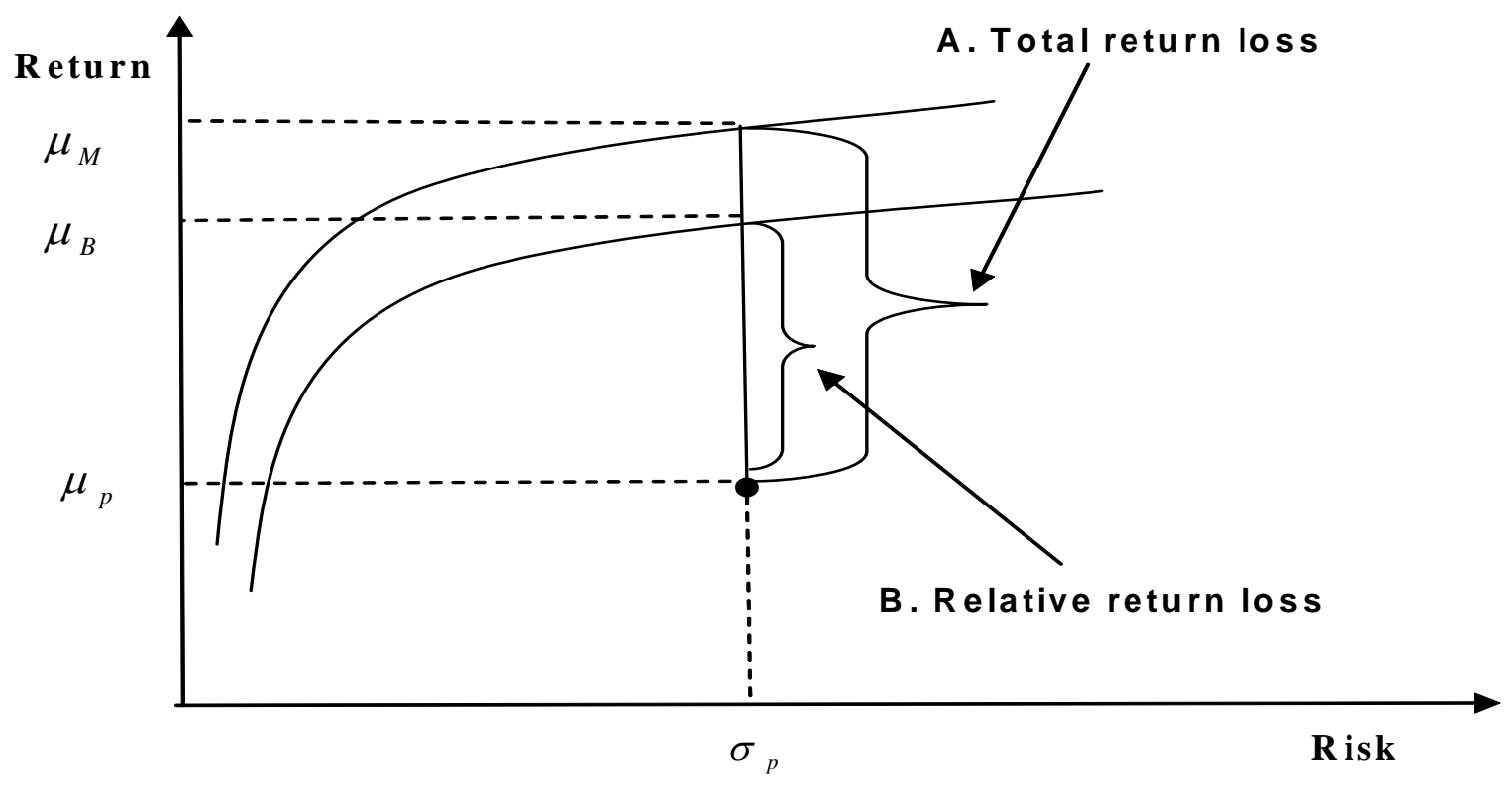

Source: Authors’ computations. 
Figure 5. Individual Portfolio Total Return Loss and Relative Return Loss Distribution.

Total Return Loss

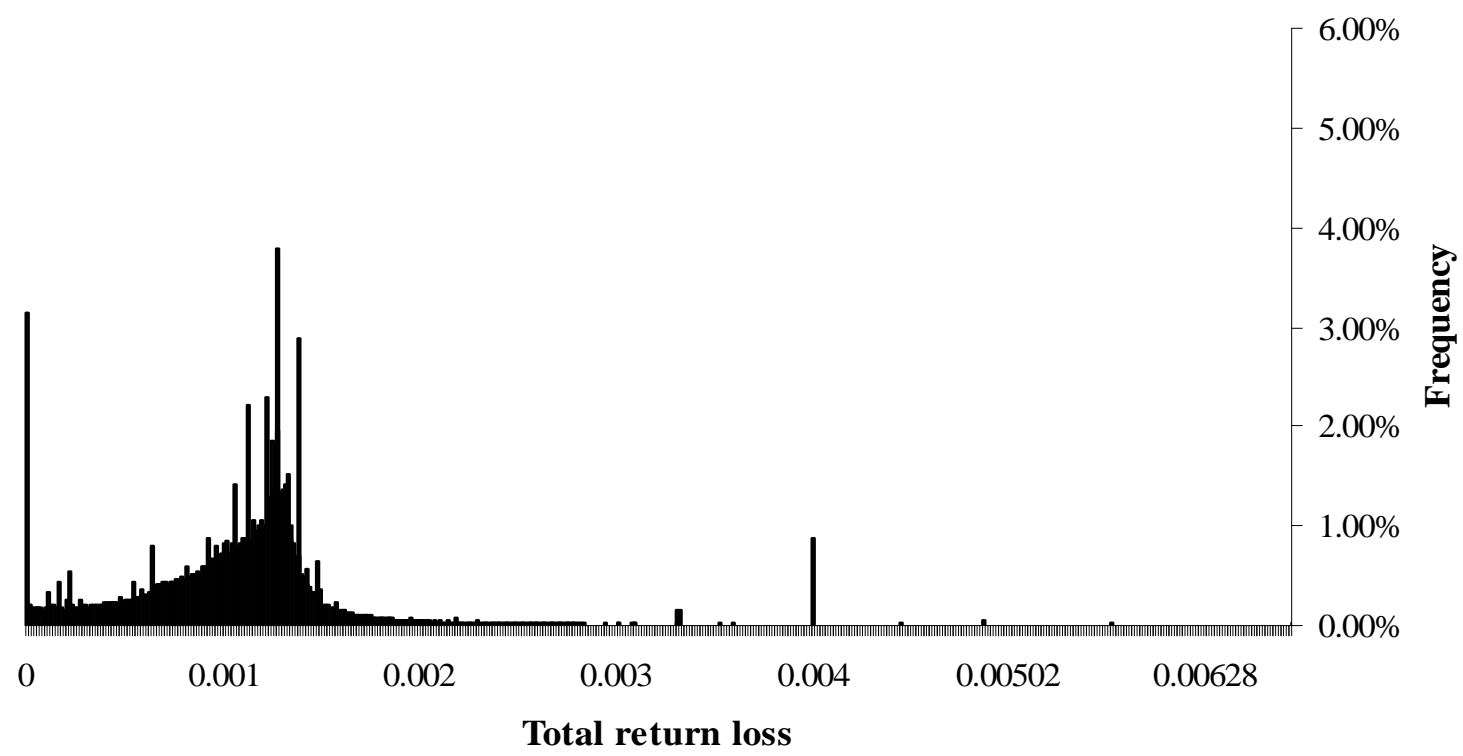

B. Relative Return Loss

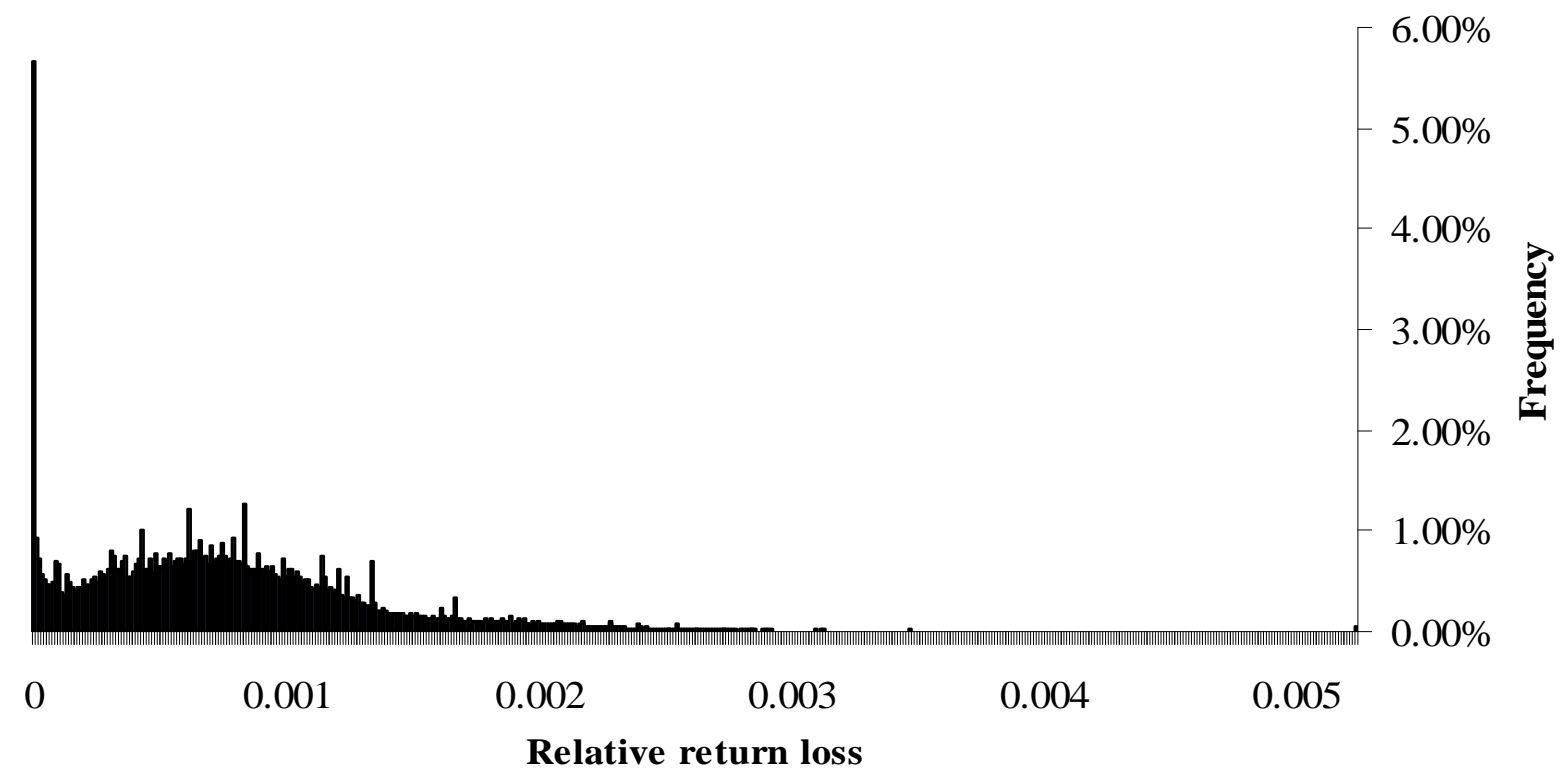

Source: Authors' computations.

Note: 986,949 participants. 
Figure 6. Individual Portfolio Idiosyncratic Risk Share Distribution

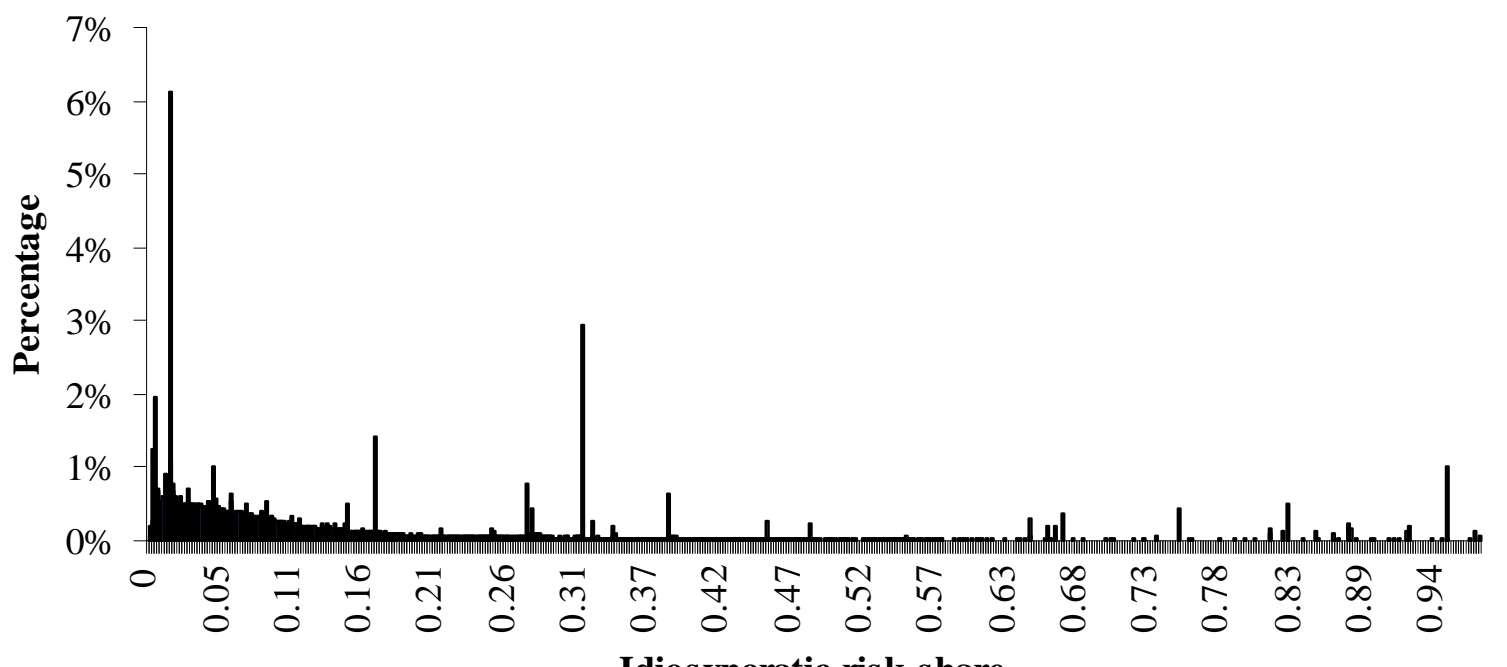

Idiosyncratic risk share

Source: Authors’ computations.

Note: 986,949 participants. 
Figure 7. Actual Portfolio Performance vs. Naive Allocation Performance

\section{A. Monthly Relative Return Loss}

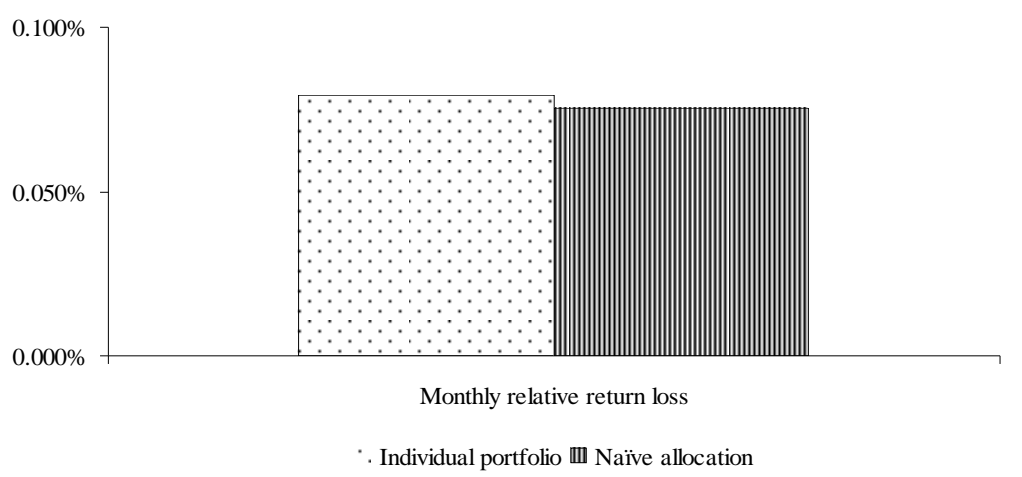

B. Idiosyncratic Risk Share

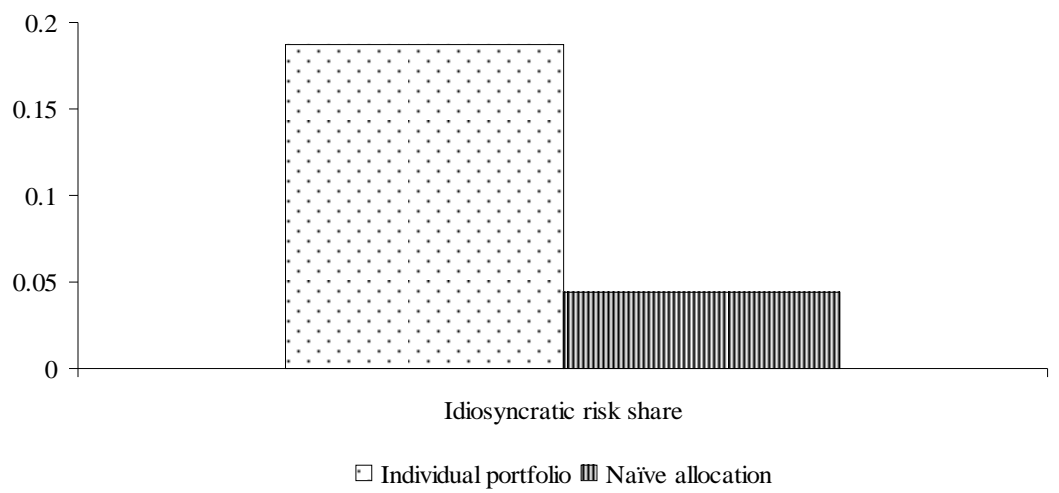

Source: Authors' computation.

Note: 986,949 participants and 1,003 plans. 
Figure 8. Performance Measures vs. Number of Funds

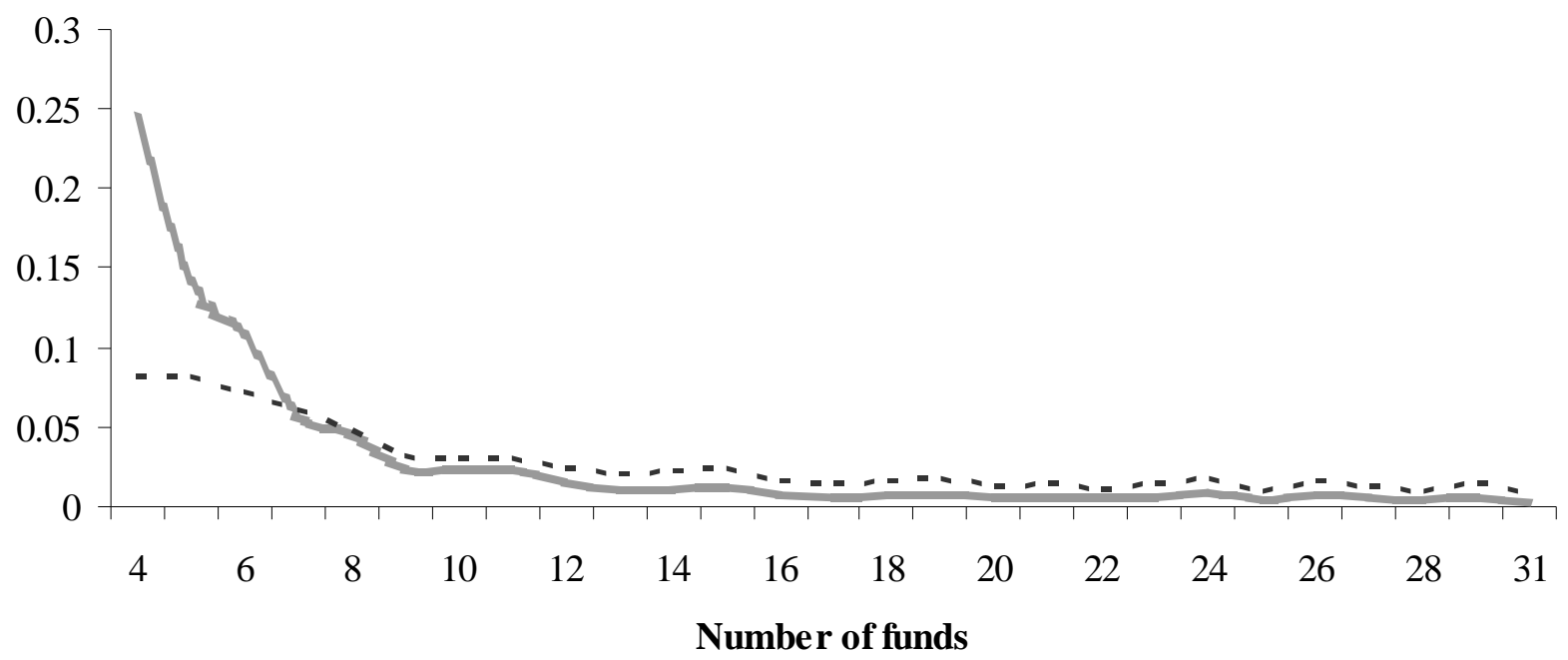

- Sharpe ratio loss - - - - Idiosyncratic risk share

Source: Authors' computations.

Note: 993 plans. 


\section{Appendix: Estimating Return Moments}

To compute each plan's performance measures, we must estimate each plan-specific mean and variance of returns. We adopt the CAPM asset pricing model and following Calvet, Campbell, and Sodini (2006) , we regress fund returns on three market indexes:

$$
R_{i t}=\beta_{i}^{1} M K T_{t}+\beta_{i}^{2} B O N D_{t}+\beta_{i}^{3} E A F E_{t}+\varepsilon_{i, t},
$$

where $R_{i, t}$ is the excess return for fund $\mathrm{i}$; $M K T$ is the excess return for Russell 3000 (broad domestic equity market); BOND is the excess return for Lehman US aggregate (broad domestic bond market); EAFE is the excess return for MSCI EAFE (international equity market); and the time period is 12/97 12/04 (or less if not available for some funds). Using the estimated risk loading $\hat{\beta}_{i}^{1}, \hat{\beta}_{i}^{2}, \hat{\beta}_{i}^{3}$ from the regression above, we can estimate moments for each fund: $\hat{\mu}_{f}=\hat{\beta} \hat{\mu}, \quad \hat{\Sigma}_{f}=\hat{\beta} \hat{\Sigma} \hat{\beta}^{\prime}+\hat{\Sigma}_{\text {idio }}$, where $\hat{\mu}_{f}$ is the vector of estimated mean excess return over all funds; $\hat{\Sigma}_{f}$ is the estimated variance-covariance matrix of excess returns over all funds; $\hat{\beta}$ is the vector of three betas over all funds $\hat{\beta}=\left(\hat{b}_{1}, \ldots, \hat{b}_{i}\right)^{\prime}, \hat{b}_{i}=\left(\hat{\beta}_{i}^{1}, \hat{\beta}_{i}^{2}, \hat{\beta}_{i}^{3}\right) ; \hat{\mu}$ is the mean excess return over three benchmark funds, $\hat{\mu}=\left(\hat{\mu}_{M K T}, \hat{\mu}_{B O N D}, \hat{\mu}_{\text {EAFE }}\right)^{\prime} ; \hat{\Sigma}$ is the variance-covariance matrix of three benchmark funds; and $\hat{\Sigma}_{\text {idio }}$ is the estimated idiosyncratic risk of funds estimated from the variance-covariance matrix of regression residuals $\varepsilon_{i, t}$.

Now, based on the estimated mean and variance of returns over all funds, we estimate moments of plans: $\hat{\mu}_{p}=\omega^{\prime} \hat{\mu}_{f}, \hat{\Sigma}_{p}=\omega^{\prime} \hat{\Sigma}_{f} \omega, \hat{\Sigma}_{\text {idio, } p}=\omega^{\prime} \hat{\Sigma}_{\text {idio }} \omega$, where $\omega$ is the weight vector over all funds in each plan. 


\section{Endnotes}

${ }^{1}$ Each employee in a plan is assigned a unique account.

${ }^{2}$ Most of the plans are 401(k) plans in private for profit firms; there are also a few 403(b) plans for the non-profit sector.

${ }^{3}$ In a handful of cases, some funds have fewer than 85 months of return observations.

${ }^{4}$ Active accounts have positive contributions over the 24-month window (for 2003-04).

${ }^{5}$ Data from IXI Corporation are used to impute non-retirement household financial wealth and household income is imputed by Claritas for 2003 using participant ZIP codes.

${ }^{6}$ Those who have elected to obtain plan information via the internet are defined as having web access.

7 Their sample includes firms filing 11-Ks in 1998 and they follow them through 2002.

8 These figures are larger than the eight in EGB's (2006) older data on 401(k) plans surveyed in 2001 by Moody’s Investor Service.

${ }^{9}$ Table 3 is computed for 986,614 participants; we lose a few participants because of missing demographic data. The efficiency measure used requires some nonzero risk exposure.

${ }^{10}$ All shares shown in Table 3 are calculated from balances.

${ }^{11}$ Russell 1000 growth, Russell 1000 value, Russell 2000 growth and Russell 2000 value respectively represent large-cap growth, large-cap value, small-cap growth and small-cap value US equity markets.

12 Blake, Elton and Gruber (1993) suggest including a high-yield bond index to capture differences in return across bond funds.

${ }^{13}$ Since only risky funds are the focus of the efficiency test (equity, balanced, bond, and company stock funds), we delete money market funds, investment contract s, and unfunded funds from the analysis sample. Brokerage option investments are also excluded as we cannot observe their returns (only 2 percent of plans offer these). All returns on mutual funds are computed after expenses and returns on eight benchmark indexes are before expenses, but since Vanguard's expenses on mutual funds are low, we avoid subtracting expenses from the indexes to avoid estimation error.

${ }^{14}$ We retain funds with positive weights in the tangency portfolio formed by the whole set of funds. 
${ }^{15}$ Money market funds, investment contract funds, unfunded funds and brokerage option funds are excluded, as we consider only the performance of risky funds (equity funds, bond funds, balanced funds, and company stock). The same applies to the idiosyncratic risk share measure discussed next.

${ }^{16}$ Vanguard (2007) reports that the median personalized annual return for participants in the defined contribution plans they manage was 6.2 percent as of 12/07; we compute the monthly return based on this number.

17 This is computed as the difference of the portfolio without the return loss, which would grow over 20 years by $(1.005+0.001093)^{240}$ versus the lower less efficient return of $(1.005)^{240}$. EGB (2006) use the same approach to demonstrate 401(k) participant losses.

18 So $(1.005+.04)^{240}$ is 160 percent higher than $(1.005)^{240}$.

${ }^{19}$ Here we do not consider money market funds, investment contract funds, unfunded funds, or brokerage options, as they are not included in the efficiency test.

${ }^{20}$ We take the ln form of number of participant and total plan assets to scale these variables.

${ }^{21}$ We exclude plans with fewer than two funds to avoid the biased conclusion caused by some extreme sample. Similar results obtain if all plans are included. 